\title{
Mental Disorders Linked to Crosstalk between The Gut Microbiome and The Brain
}

\author{
Tae-Yong Choi ${ }^{1 *}$, Young Pyo Choi ${ }^{2}$ and Ja Wook Koo ${ }^{1 *}$ \\ ${ }^{1}$ Emotion, Cognition and Behavior Research Group, Korea Brain Research Institute (KBRI), ${ }^{2}$ Laboratory Animal Center, \\ Korea Brain Research Institute (KBRI), Daegu 41062, Korea
}

\begin{abstract}
Often called the second brain, the gut communicates extensively with the brain and vice versa. The conversation between these two organs affects a variety of physiological mechanisms that are associated with our mental health. Over the past decade, a growing body of evidence has suggested that the gut microbiome builds a unique ecosystem inside the gastrointestinal tract to maintain the homeostasis and that compositional changes in the gut microbiome are highly correlated with several mental disorders. There are ongoing efforts to treat or prevent mental disorders by regulating the gut microbiome using probiotics. These attempts are based on the seminal findings that probiotics can control the gut microbiome and affect mental conditions. However, some issues have yet to be conclusively addressed, especially the causality between the gut microbiome and mental disorders. In this review, we focus on the mechanisms by which the gut microbiome affects mental health and diseases. Furthermore, we discuss the potential use of probiotics as therapeutic agents for psychiatric disorders.
\end{abstract}

Key words: Gastrointestinal microbiome, Brain, Mental disorders, Probiotics

\section{INTRODUCTION}

The microbiome is the sum of "microbe" and "biome," which is defined as microorganisms coexisting with host organisms and their theater of activity, including genetic information. The human microbiome is found in various areas of the body, such as the skin, placenta, uterus, vagina, oral cavity, and gut. Approximately 95\% of the human microbiome is found in the digestive system, including the large intestine [1]. This is called the gut microbiome. Recent studies have shown that the gut microbiome is important for maintaining brain homeostasis in host organisms. For example, compositional changes in the gut microbiome are closely associ-

Submitted September 23, 2020, Revised October 21, 2020,

Accepted October 22, 2020

* To whom correspondence should be addressed.

Tae-Yong Choi, TEL: 82-53-980-8439, FAX: 82-53-980-8399

e-mail: tychoi5667@kbri.re.kr

Ja Wook Koo, TEL: 82-53-980-8430, FAX: 82-53-980-8399

e-mail: jawook.koo@kbri.re.kr ated with several mental disorders, which can be improved by controlling the gut microbiome composition [2-4].

Classically, mental disorders are known to be caused by structural abnormalities or dysfunction of the brain. For example, structural, molecular, or physiological changes in the mesolimbic dopamine system, which is primarily involved in rewarding and motivational behaviors, are the main pathophysiological mechanisms of depression [5]. For more than a decade, however, accumulating evidence suggests that another participant, the gut microbiome, is involved in maintaining normal mental health and the pathogenesis of mental disorders.

In this review, we will focus on the mechanism underlying the impact of the gut microbiome on mental condition. Moreover, we will discuss the potential use of probiotics, microorganisms that have beneficial effects on the health of the host, in the treatment of some psychiatric disorders. First, we summarize recent findings that reveal the relationship between the gut microbiome and mental health and diseases. Next, we examine the main pathways through which the gut microbiome communicates with the nervous system. Finally, we discuss the types of probiotics and the
Copyright $\odot$ Experimental Neurobiology 2020. www.enjournal.org
This is an Open Access article distributed under the terms of the Creative Commons Attribution Non-Commercial License (http://creativecommons.org/licenses/by-nc/4.0) which permits unrestricted non-commercial use, distribution, and reproduction in any medium, provided the original work is properly cited. 
mechanism by which they improve mental disorders.

\section{GUT MICROBIOME AND MENTAL DISORDERS}

Recent studies have revealed that controlling the gut microbiomes of the experimental animals confirmed various behavioral changes, including social, emotional and cognitive functions. This suggests that the gut microbiome affects the pathogenesis of many mental disorders. In this section, we summarize the changes in the gut microbiome found in several kinds of mental disorders.

\section{Major depressive disorder (MDD)}

Major depressive disorder (MDD), commonly known as depression, is a common but serious mental disorder with low mood, feelings of hopelessness, and anxiety. The cause of MDD is unclear, but it is widely accepted that severe and/or prolonged stress is the leading cause of this disorder. Stress affects many physiological states, such as the synthesis or secretion of stress hormones including corticosterone or neurotransmitters related to mood, including dopamine and serotonin. Changes in the structure or function of the brain reward system or immune system are also influenced by stress [5]. Collectively, these changes are thought to cause MDD.

Many preclinical and clinical studies have reported that compositional changes in the gut microbiome are highly linked to these disorders. Germ-free (GF) animals usually exhibit antidepressantlike behaviors [6-8], but antibiotic-induced gut dysbiosis elicited depression-like behaviors $[9,10]$. Compositional changes in the gut microbiome were observed in several animal models of stressinduced depression. Chronic social defeat stress (CSDS) increased Proteobacteria and Verrucomicrobia, but decreased Chloroflexi in the gut [11]. Another study using the CSDS protocol reported that Bifidobacterium was increased in resilient, but not susceptible, animals. Of note, the depressive phenotypes induced by this stress protocol were recovered by administrating these bacteria [12] Different stress protocol - chronic unpredictable stress (CUS) also altered the composition of microorganisms in the gut. For example, Lactobacillus was decreased in CUS-induced depressive animals, and the treatment of probiotic $L$. reuteri rescued depressive behaviors induced by the CUS protocol [13]. Recently, it was reported that delivering the gut microbiome from stressed animals to healthy controls induced depression-like phenotypes in recipient animals such as despair-like behavior and decreased neurogenesis in the hippocampus [14].

Conflicting results have also been reported in human studies. One group reported that the diversity of the gut microbiome was higher in patients with depression than in the healthy group [15]. However, other reports showed that this diversity was not observed in patients with MDD [16, 17]. Some clinical studies showed that Bifidobacterium, Lactobacillus and Bacteroidetes were reduced [18, 19], but Actinobacteria, Firmicutes, and Faecalibacterium were increased in patients with MDD compared to healthy controls [18, 20-22]. We summarized the main findings that report gut dysbiosis in patients with depression in Table 1. These results suggest a high correlation between gut dysbiosis and depression in animal and human studies. However, more detailed research is needed on the causal relationship between changes in the gut microbiome and depression for treating or preventing this disorder by regulating the gut microbiome.

\section{Anxiety disorder}

Anxiety disorder is a mental disorder in which people feel abnormal and excessive anxiety that makes daily life difficult. It is categorized by symptoms such as generalized anxiety disorder, phobia, panic disorder and post-traumatic stress disorder (PTSD). Anxiety symptoms also accompany many chronic diseases such as cancer, chronic fatigue syndrome (CFS), and irritable bowel syndrome. Anxiety and the gut microbiome are closely related. GF and antibiotic-treated animals usually showed anxiolytic behaviors, such as increased time in the center zone during OFT or in open arms during EPM [6, 23-30]. Some clinical reports have shown that the administration of probiotics improved anxiety symptoms in healthy humans [31-33] or patients with CFS [34]. These results suggest that anxiety disorders can be improved through the control of the gut microbiome using probiotics, but further research to reveal the detailed mechanisms is needed.

\section{Autism spectrum disorder (ASD)}

Autism spectrum disorder (ASD) is a neurodevelopmental disease characterized by repetitive behaviors and impairment of social or cognitive function. Some human studies have reported the relationship between the gut microbiome and ASD. Many patients with ASD have gut trouble, such as bloating and diarrhea, and the treatment of vancomycin, broad-spectrum antibiotics, improved behavioral deficits in patients with ASD $[35,36]$. Several studies have reported that patients with ASD have a different composition of the gut microbiome compared to healthy controls: levels of the advantageous bacteria Bifidobacterium were decreased, but the pathogenic bacteria Desulfovibrio and Clostridia were increased in the gut of patients with ASD [37]. It was also reported that Firmicutes/Bacteroidetes ratio is increased in patients with ASD [3841]. Table 2 shows the major changes in the gut microbiome of patients with ASD.

Sometimes, deficits in sociability, the most representative behavioral change in ASD, were observed in GF animals [25, 42-45] 
Table 1. Gut dysbiosis observed in human patients with MDD

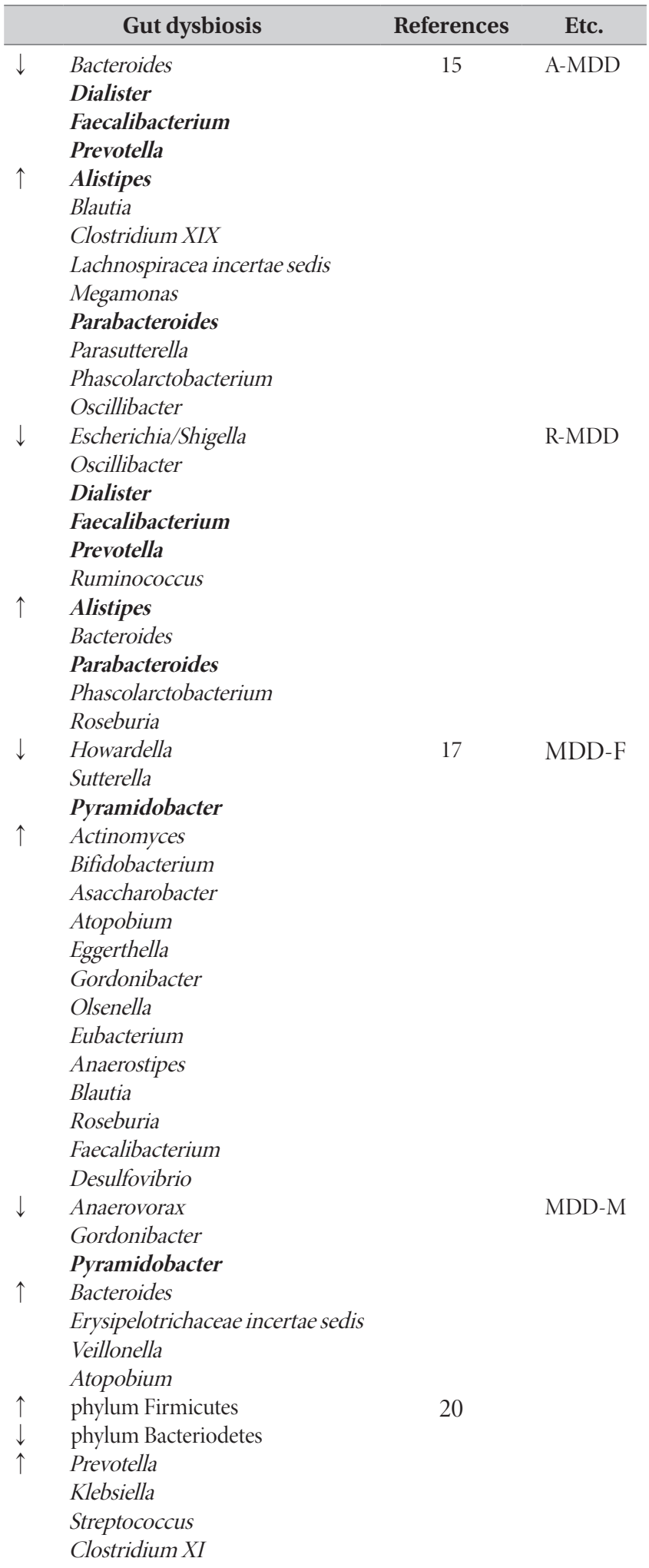

${ }^{a} \downarrow$, decreased compared to control; $\uparrow$, increased compared to control.

${ }^{b} \mathrm{~A}-\mathrm{MDD}$, active-major depressive disorder; R-MDD, responded-major depressive disorder; MDD-F, female patients with MDD; MDD-M, male patients with MDD.

${ }^{c}$ Duplicate bacteria are indicated in bold.
Table 2. Gut dysbiosis observed in other human mental disorders

\begin{tabular}{|c|c|c|c|}
\hline Disorders & & Gut dysbiosis & References \\
\hline $\begin{array}{c}\text { Autism spectrum } \\
\text { disorder (ASD) }\end{array}$ & $\begin{array}{l}\downarrow \\
\uparrow\end{array}$ & $\begin{array}{l}\text { phylum Bacteroidetes } \\
\text { phylum Firmicutes } \\
\text { Streptococcus } \\
\text { Veillonella } \\
\text { Escherichia } \\
\text { Actinomyces } \\
\text { Parvimonas } \\
\text { Bulleidia } \\
\text { Peptoniphilus }\end{array}$ & 40 \\
\hline & $\downarrow$ & $\begin{array}{l}\text { Akkermansia } \\
\text { Bacteroides } \\
\text { Bifidobacterium } \\
\text { Parabacteroides } \\
\text { Enterococcus } \\
\text { Escherichia coli } \\
\text { Bacteroides } \\
\text { Bifidobacterium } \\
\text { Faecalibacterium } \\
\text { Lactobacillus }\end{array}$ & 41 \\
\hline Alcoholism & $\uparrow$ & $\begin{array}{l}\text { phylum Proteobacteria } \\
\text { Sutterella } \\
\text { Holdemania } \\
\text { Clostridium } \\
\text { Faecalibacterium }\end{array}$ & 52 \\
\hline $\begin{array}{l}\text { Alzheimer's } \\
\text { disease (AD) }\end{array}$ & $\downarrow$ & $\begin{array}{l}\text { phylum Firmicutes } \\
\text { phylum Actinobacteria } \\
\text { Bifidobacterium } \\
\text { Dialister } \\
\text { Clostridium } \\
\text { Turicibacter } \\
\text { Adlercreutzia } \\
\text { phylum Bacteroidetes } \\
\text { Blautia } \\
\text { Bacteroides } \\
\text { Alistipes } \\
\text { Phascolactobacterium } \\
\text { Bilophila } \\
\text { Gemella }\end{array}$ & 69 \\
\hline
\end{tabular}

$\downarrow$, decreased compared to control; $\uparrow$, increased compared to control.

and in antibiotic-treated animals $[10,30]$. Many animal models of autism have shown gut dysbiosis. For example, shank 3 (autism candidate gene) transgenic mice had differences in the composition of the gut microbiome with reduced Veillonella, Prevotella and Lactobacillus. Autistic behavioral phenotypes observed in shank 3 transgenic mice were ameliorated by the administration of $L$. reuteri $[46,47]$. In utero exposure to valproic acid (VPA), another animal model for ASD, also induced gut dysbiosys similarly observed in ASD patients [48].

\section{Addiction}

Addiction is a chronic brain disease defined as compulsive substance use despite negative consequences. Recent studies have 
revealed that the gut microbiome is involved in this disorder. Alcohol, the most common addictive substance, changes the gut microbiome both in humans and in experimental animals [49-52]. We summarized the main findings that report gut dysbiosis in patients with alcoholism in Table 2.

Rats susceptible to compulsive alcohol-seeking behavior showed increased Firmicutes and decreased Actinobacteria [53]. Alcoholic hepatitis was recovered by the treatment of L. rhamnosus GG [54]. Several animal studies have shown that gut dysbiosis is also induced by opioids [ 55, 56], cannabis [57], and tobacco [58, 59]. Interestingly, gut dysbiosis caused by the treatment of antibiotics increased conditioned place preference and behavioral sensitization induced by low ( $5 \mathrm{mg} / \mathrm{kg})$, but not high ( $10 \mathrm{mg} / \mathrm{kg})$, concentrations of cocaine [60].

\section{Alzheimer's disease (AD)}

Alzheimer's disease (AD) is a typical neurodegenerative disease that induces dementia. It progressively worsens cognitive function, including memory. Although the exact mechanisms and causes of this disease are not fully known, it is thought that various complex pathological mechanisms, including the accumulation of beta-amyloid $(A \beta)$, hyperphosphorylation of the tau protein, and immune responses are involved [61]. Some reports indicate that microorganisms are involved in the pathogenesis of AD. For example, amyloid, one of the main molecules related to $\mathrm{AD}$, was generated from the gut microbiome [62-64], and acted as an antimicrobial peptide $[65,66]$. Other studies have shown that $A \beta$ pathology is modulated by the gut microbiome. APP/PS1 transgenic mice, an AD mouse model with human transgenes for APP bearing the Swedish mutation and L166P-mutated PSEN1, lacking gut microbiome showed a decreased $A \beta$ pathology compared to the same transgenic mice with a normal gut microbiome [67]. Similarly, antibiotic treatment in young APP/PS1 transgenic mice resulted in decreased A $\beta$ deposition [68]. Clinically, alterations in the composition of the gut microbiome in patients with $\mathrm{AD}$, such as a reduction of Firmicutes and an enhancement of Bacteroidetes, have been reported [69]. Table 2 shows the major changes in the gut microbiome of patients with AD.

Of note, probiotics can affect $\mathrm{AD}$ pathology. A probiotic cocktail decreased oxidative stress, one of $\mathrm{AD}$ pathologies, in a triple transgenic mouse model ( $3 \mathrm{xTg}$ ), another $\mathrm{AD}$ mouse model containing three mutations related to familial AD (APP Swedish, MAPT P301L, and PSEN1 M146V) [70]. Another preclinical study revealed that cognitive impairment in $\mathrm{AD}$ animals induced by direct injection of $A \beta$ in the hippocampus was recovered by another probiotic mixture with different combinations [71]. Cognitive deficits in patients with $\mathrm{AD}$ were also recovered by administering a mixture of probiotics, including L. acidophilus, L. casei, L. fermentum and B. bifidum [72]. Not only the probiotic treatment but also FMT ameliorated AD pathogenesis. FMT from healthy animals to $\mathrm{AD}$ animal models ameliorated the cognitive deficits and immune responses of recipient AD animals [73]. More studies are needed to reveal how the regulation of the gut microbiome improves $\mathrm{AD}$.

\section{COMMUNICATION BETWEEN GUT MICROBIOME AND THE BRAIN}

The gut, sometimes called the 'second brain', interacts with the brain despite the distance between these two organs. While the gut microbiome exists in the gastrointestinal (GI) tract, it is involved in various normal behaviors and mental disorders. This raises the question of how the gut microbiome, gut and brain communicate?

\section{Enteric nervous system (ENS)}

In contrast to other peripheral organs, the GI tract has an intrinsic nervous system with numerous neurons (approximately 500 million cells in humans) and glial cells called the enteric nervous system (ENS). This system is a mesh-like neural network distributed from the esophagus to the anus. The ENS is composed of two ganglionated plexi; the myenteric and submucosal plexuses. They are connected by the central nervous system (CNS) and directly control the movement of the GI tract and the secretion of gut hormones and gastric acid $[74,75]$. ENS neurons produce various neurotransmitters, including dopamine and serotonin, to communicate with other neurons inside or outside this system [76, 77]. Communication by ENS neurotransmitters is also affected by the gut microbiome and its metabolites because they are anatomically adjacent. For example, the gut microbiome affects ENS function via the recognition of microbial molecules by toll-like receptors (TLRs) [78].

\section{Vagus nerve}

The vagus nerve, a part of the parasympathetic nervous system that regulates involuntary body functions such as digestion, respiration, and heartbeat, is the tenth cranial nerve that connects the gut and the brain. It gathers information from various organs such as the GI tract and respiratory and cardiovascular systems. For example, vagal afferents sense physical changes in the gut, such as stretch and tension, or detect metabolites from the gut microbiome or gut hormones. Their cell bodies are located in the nodose ganglia and are connected to many nuclei of the brainstem. In particular, vagal fibers connected to the GI tract are linked to the nucleus of the solitary tract (NTS). Excitatory synapses from the NTS are connected to the paraventricular hypothalamic nuclei 
$(\mathrm{PVN})$ and parabrachial nucleus (PBN). These areas project to the midbrain, including the substantia nigra pars compacta $(\mathrm{SNc})$ and ventral tegmental area (VTA), two major brain regions to make dopamine. Thus, manipulating the vagus nerve may regulate motivational and reward behaviors by affecting dopamine release to the striatum, medial prefrontal cortex (mPFC), or other brain regions [79-81].

Two therapeutic methods, vagotomy and vagus nerve stimulation, provide insight into the role of the vagus nerve in communicating between the gut and the brain. Interestingly, damage to the vagus nerve caused by gastrectomy to treat peptic ulcers increases some psychiatric disorders [82]. Vagotomy in adult mice reduces brain-derived neurotrophic factor (BDNF) expression and neurogenesis in the hippocampus [83]. Comparably, anxiolytic phenotypes were observed in vagotomized rats [84]. Vagus nerve stimulation is usually used to treat depression and chronic pain $[85,86]$. In contrast to vagotomy in rodents, the electrical stimulation of the vagus nerve increases cell proliferation and BDNF expression in the hippocampus [87]. These results suggest that communication between the gut and brain through the vagus nerve is important for maintaining brain homeostasis.

\section{Spinal cord}

The gut and brain are physically connected through not only the vagus nerve but also the spinal cord. Although the vagus nerve relays the physiological information from the gut, it is well established that noxious information, including pain and injury, is conveyed through the spinal cord. For example, vagotomy, but not spinal transection, inhibits the delivery of information about nutrition sensing in the gut or mechanical stretch of the stomach $[88,89]$. However, visceral pain occurs when the sensory neurons in the gut are sensitized, and the ascending spinal neurons are subsequently over-activated $[90,91]$. In addition, spinal cord injury results in GI dysfunction, including enhanced intestinal permeability and gut dysbiosis, microbial imbalance or maladaptation on or inside the body. The imbalance of the gut microbiome induced by spinal cord injury also affects neurological function $[92,93]$. These results indicate that the spinal cord is important for health and behaviors through monitoring and controlling the gut.

\section{Immune system}

Various microorganisms that exist in the gut do not directly affect the GI tract because there is a physical barrier between these two systems. Viscous mucus is secreted from goblet cells in the gut and inhibits direct contact between the gut microbiome and gut tissues. Despite this physical barrier, many immune cells located in the gut can interact with gut bacteria. Other cell types, such as enterocytes that synthesize and secrete cytokines and chemokines, also exist in the gut epithelium [94]. In addition to goblet cells releasing mucus in the gut, enteroendocrine cells in the GI tract produce various neuroendocrine molecules such as ghrelin and somatostatin [95]. Antigens present in the gut bacteria, such as peptidoglycans and polysaccharides, are recognized by epithelial pattern recognition receptors, and the immune system is activated [96]. On the other hand, hormones from the brain, such as cortisol secreted from the hypothalamus-pituitary-adrenal (HPA) axis, affect gut immune function and gut permeability [97].

\section{Neurotransmitters}

Among the byproducts produced by the gut microbiome, neurotransmitters act directly on the nervous system. Serotonin (also called 5-hydroxytryptophan or 5-HT), a neurotransmitter known as a happiness hormone because of its major function in experiencing happiness by regulating mood, is mainly synthesized in enterochromaffin cells in the gut. Intriguingly, the production of 5 -HT is affected by the gut microbiome. For example, Clostridium perfringens, one of the gut microbiomes in humans and rodents, is involved in the synthesis of 5 -HT in the gut $[76,77,98]$. The gut microbiome also affects the production of another neurotransmitter, dopamine, or its precursor molecule L-DOPA (L-3,4dihydroxyphenylalanine), also known as levodopa. Tyrosine decarboxylases from Enterococcus faecalis found in the GI tract of mammals convert L-DOPA to dopamine in the intestine, regulating the level of L-DOPA in the serum $[99,100]$. Oral administration of another gut microbiome, Lactobacillus reuteri, in adult mice increased serum dopamine [101]. Moreover, a major inhibitory neurotransmitter, gamma-aminobutyric acid (GABA), is synthesized by lactic acid bacteria [102]. These neurotransmitters produced in the gut are thought to be utilized for communicating with the brain, but a detailed mechanism remains unknown. However, it is certain that serotonin and dopamine produced in the gut cannot transport to the brain directly because these molecules do not pass the blood-brain barrier. These neurotransmitters are thought to act directly on neurons or other cell types in the GI tract. Another possibility is that the precursors of these neurotransmitters, such as tryptophan or L-DOPA, produced in the gut are delivered to the brain for conversion into neurotransmitters. More research is needed on the mechanism by which neurotransmitters produced in the gut regulate brain function and affect behaviors.

We summarized previously described pathways to communicate between the gut and the brain and the relationship of gut dysbiosis and mental disorders in Fig. 1. 


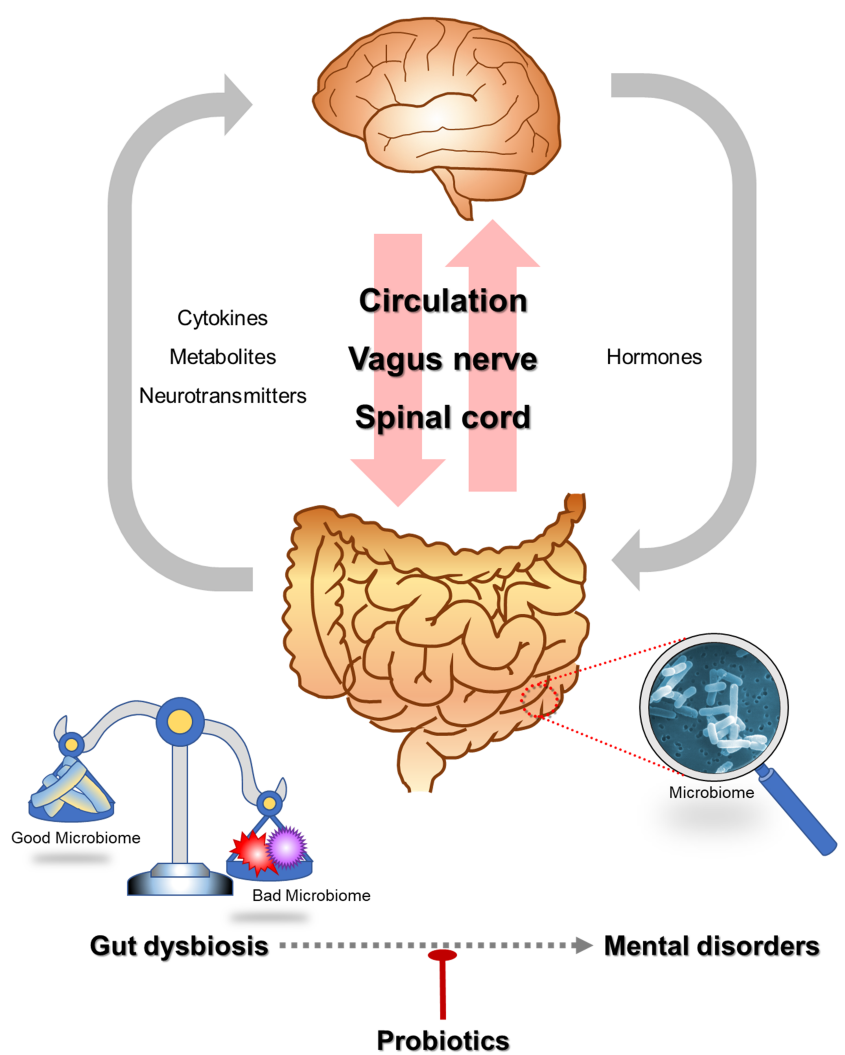

Fig. 1. Communication between the gut and the brain and the relationship of gut dysbiosis and mental disorders.

\section{HOW TO STUDY THE ROLE OF THE GUT MICROBIOME ON MENTAL HEALTH AND DISEASES}

Many recent studies have revealed a high correlation between human mental disorders and changes in the gut microbiome. However, this correlation does not prove a causal relationship in the onset of mental disorders following changes in the gut microbiome. To explain this causality, it is necessary to observe whether behavioral changes are induced by artificially controlling gut microbiomes using experimental animal models. Table 3 shows several types of behavioral changes induced by the alteration of the gut microbiome, as described below.

\section{Germ free (GF) animals}

The surest way to identify the role of an element is to observe what changes occur when the element is removed. We can know how the gut microbiome affects our mental health and behavior through GF animals who do not have microorganisms in or on their bodies. GF animals display different physiology and behavior compared to animals containing a normal microbiome. Many groups reported that the basal locomotor activity of GF animals
Table 3. Various behavioral changes observed in GF animals or by antibiotics-treated gut dysbiosis

\begin{tabular}{|c|c|c|c|}
\hline Behaviors & Changes & $\begin{array}{l}\text { Animal } \\
\text { models }\end{array}$ & $\begin{array}{l}\text { Behavioral methods } \\
\text { (references) }\end{array}$ \\
\hline \multirow[t]{3}{*}{ Basal locomotion } & $\leftrightarrow$ & GF & $\begin{array}{l}\text { Open field test }(23,26,28 \text {, } \\
103)\end{array}$ \\
\hline & & $\mathrm{ABX}$ & Open field test $(9,30,105)$ \\
\hline & $\uparrow$ & GF & Open field test $\left(24,25^{\star}, 27\right)$ \\
\hline \multirow[t]{10}{*}{ Anxiety } & $\downarrow$ & GF & $\begin{array}{l}\text { Open field test }(23,24,27 \text {, } \\
28)\end{array}$ \\
\hline & & & $\begin{array}{l}\text { Novelty suppressed feeding } \\
\text { test (23) }\end{array}$ \\
\hline & & & Light-dark test $(6,24)$ \\
\hline & & & $\begin{array}{l}\text { Elevated plus maze test (25, } \\
26)\end{array}$ \\
\hline & & $\mathrm{ABX}$ & Light-dark test (29) \\
\hline & & & Elevated plus maze test (30) \\
\hline & $\uparrow$ & GF & Open field test $(42,103)$ \\
\hline & $\leftrightarrow$ & GF & Light-dark test (104) \\
\hline & & $\mathrm{ABX}$ & Open field test $(9,105)$ \\
\hline & & & $\begin{array}{l}\text { Elevated plus maze test }(9 \text {, } \\
105)\end{array}$ \\
\hline \multirow[t]{5}{*}{ Depression } & $\downarrow$ & GF & Tail suspension test $(6,8)$ \\
\hline & & & Forced swim test $(7,8)$ \\
\hline & & & Sucrose preference test (8) \\
\hline & $\uparrow$ & $\mathrm{ABX}$ & Forced swim test $(9,10)$ \\
\hline & & & Tail suspension test (10) \\
\hline \multirow[t]{4}{*}{ Social interaction } & $\downarrow$ & GF & $\begin{array}{l}3 \text {-chamber social interac- } \\
\text { tion test }\left(25^{\star}, 43,44,45\right)\end{array}$ \\
\hline & & & Social interaction test (42) \\
\hline & & $\mathrm{ABX}$ & $\begin{array}{l}\text { 3-chamber social interac- } \\
\text { tion test }\left(10^{* \star}, 30\right)\end{array}$ \\
\hline & $\uparrow$ & GF & $\begin{array}{l}\text { 3-chamber social interac- } \\
\text { tion test (27) }\end{array}$ \\
\hline \multirow[t]{6}{*}{ Cognition } & $\downarrow$ & GF & $\begin{array}{l}\text { Nobel object recognition } \\
\text { test }(25,104)\end{array}$ \\
\hline & & & T-maze test (104) \\
\hline & & $\mathrm{ABX}$ & $\begin{array}{l}\text { Nobel object recognition } \\
\text { test }(29,105,106)\end{array}$ \\
\hline & & & Morris water maze test (9) \\
\hline & $\leftrightarrow$ & $\mathrm{ABX}$ & Barnez maze test (105) \\
\hline & & & $\begin{array}{l}\text { Nobel object recognition } \\
\text { test (9) }\end{array}$ \\
\hline
\end{tabular}

${ }^{a} \leftrightarrow$, no changes; $\uparrow$, increase; $\downarrow$, decrease; GF, germ-free animals; ABX, antibiotics.

${ }^{b_{\star}}$ female only; ${ }^{* *}$ normal sociability, but reduced social novelty.

was similar to that of control animals $[23,26,28,103$; but see ref. $24,25,27]$. Anxiolytic behaviors such as increased time and movement in the center zone during the open field test (OFT) and increased time in the open arm during the elevated plus maze (EPM) test were also observed in GF animals [6, 23-28; but see ref. 42, 103]. Social behavior was also decreased in GF animals [25, 42-45; but see ref. 27]. Some anti-depressive behavioral phenotypes were also observed in GF animals; GF mice showed reduced immobile 
time during behavioral despair tests such as the forced swimming test (FST) or tail suspension test (TST), and increased sucrose preference, suggesting hedonic behavior [6-8]. In addition, cognitive impairment in GF animals has been observed in some studies. Recognition memory and working memory were impaired in GF mice, as shown by performance in the novel object recognition test and T-maze spontaneous alternation test $[25,104]$. Taken together, the gut microbiome affects many aspects of behaviors such as locomotive, emotional, social and cognitive behaviors, but not in a consistent manner.

\section{Antibiotics-induced gut dysbiosis}

Antibiotics are usually used to treat bacterial infections by inhibiting or killing the growth of bacteria. Antibiotic-induced gut dysbiosis is another good model to study the role of the gut microbiome in mental health and disease. It has the advantage of being able to control some microbes by using selective antibiotics or their combination at specific times. Gut microbiome studies through the use of antibiotics may explain abnormalities in brain and behavior caused by antibiotic prescriptions observed in humans.

Many behavioral changes were observed in antibiotic-treated animals, similar to those observed in GF animals. Antibiotic-treated animals usually showed anxiolytic behaviors such as increased time in the light chamber during the light-dark test or increased time in the open arms during EPM [29, 30; but see ref. 9, 105]. Impairment of social behavior was also observed in antibiotic-treated animals $[10,30]$. Gut dysbiosis by antibiotics induced cognitive impairment: object recognition memory was reduced in antibiotic-treated animals compared to control $[29,105,106]$. In contrast to GF animals showing anti-depressive behaviors, antibiotic-treated animals showed depression-like behaviors such as increased immobility time during TST or FST $[9,10]$. On the other hand, locomotion was not changed by antibiotics $[9,30,105]$. These results indicate that gut dysbiosys induced by administering antibiotics induce several behavioral changes similar to those observed in GF animals.

\section{Fecal microbiota transplant (FMT)}

Fecal microbiota transplant (FMT), as known as stool transplant, is a process of transferring the gut microbiome from one individual to another. Known as an effective treatment for Clostridioides difficile infection (CDI) [107], it is also used to study the function of the gut microbiome in experimental animals. Some studies have shown that FMT from depressed patients to normal experimental animals delivered depressive-like physiological and behavioral phenotypes $[18,108]$. In addition, transplanting the gut micro- biome from obese mice chronically consuming a high-fat diet to normal mice induced anxiety-like behavior, memory impairment, and increased body fat $[109,110]$. These results suggest that the gut microbiome contains information about the mental health of the host. Decoding information from the gut microbiome would be helpful in understanding the etiology and pathophysiology of psychiatric disorders.

\section{PROBIOTICS FOR THE PREVENTION OR THE TREATMENT OF MENTAL DISORDERS}

Probiotics are living microorganisms that provide benefits to our body when ingested. Among them, bacteria that are beneficial to mental health are called psychobiotics. We previously confirmed that symptoms of various mental disorders were improved by several kinds of bacteria or their combinations [12, 13, 31-34, 70-72].

Bifidobacteria and Lactobacillus families are the most commonly used probiotics for many disorders. Some strains of these families make GABA and serotonin, which are involved in regulating cognition and emotion and are the potential target mechanisms to improve many symptoms of mental disorders [111, 112]. The effects of Bifidobacteria and Lactobacillus have been confirmed in some animal experiments. Stress-induced depression-like behaviors observed in experimental animals were recovered by the administration of these bacteria $[12,13]$. In addition, L. reuteri ameliorated the impaired social behavior observed in ASD animal models [46, 47]. Anxiety- and depression-like behaviors observed in early life stressed (ELS) animals were recovered by the treatment of $L$. plantarum PS128, which reduced inflammation and corticosterone and increased dopamine and serotonin $[113,114]$. Another study reported that behavioral changes induced by chronic restraint stress were rescued by L. helveticus NS8, which increased serotonin and BDNF in the hippocampus [115]. The effectiveness of probiotics has been proven not only in animal research, but also in human studies. For example, chronic administration of B. longum 1714 relieved stress and increased cognitive function in healthy humans [116]. These two families also recovered cognitive deficits in $\mathrm{AD}$ animal models $[70,71]$. The representative probiotics used to treat or to ameliorate mental disorders are summarized in Table 4.

Various bacteria can be used as probiotics. However, it is unknown how they positively and precisely affect people's health and treat several diseases. To use probiotics more effectively, it is necessary to know what kinds of metabolites or byproducts of probiotics are produced and how they work. 
Table 4. Probiotics used to treat mental disorders

\begin{tabular}{|c|c|c|c|c|}
\hline $\begin{array}{l}\text { Disorders or } \\
\text { models }\end{array}$ & Subjects & Probiotics & Suggested mechanisms & Ref. \\
\hline \multirow[t]{5}{*}{$\begin{array}{l}\text { Major depressive } \\
\text { disorder (MDD) }\end{array}$} & Human & $\begin{array}{l}\text { Lactobacillus helveticus R0052 and Bifido- } \\
\text { bacterium longum R0175 }\end{array}$ & & 31 \\
\hline & Mouse (CSDS) & Bifidobacterium & & 12 \\
\hline & Mouse (CUS) & Lactobacillus reuteri & $\begin{array}{l}\text { Regulating tryptophan-kynurenine pathway } \\
\text { metabolites }\end{array}$ & 13 \\
\hline & Mouse (ELS) & Lactobacillus plantarum PS128 & $\begin{array}{l}\text { Reducing serum corticosterone and inflamma- } \\
\text { tory cytokines, increasing anti-inflammatory } \\
\text { cytokines, modulating DA and 5-TH in PFC }\end{array}$ & 114 \\
\hline & Rat (CRS) & Lactobacillus helveticus NS8 & $\begin{array}{l}\text { Reducing plasma stress hormones, regulating } \\
\text { cytokines, and increasing hippocampal BDNF }\end{array}$ & 115 \\
\hline \multirow[t]{6}{*}{ Anxiety } & Human & $\begin{array}{l}\text { Lactobacillus helveticus R0052 and Bifido- } \\
\text { bacterium longum R0175 }\end{array}$ & & 31 \\
\hline & Human & $\begin{array}{l}\text { Streptococcus thermophilus, Lactobacillus } \\
\text { bulgaricus, Lactococcus lactis, Lactobacil- } \\
\text { lus acidophilus, Streptococcus thermo- } \\
\text { philes, Lactobacillus plantarum, Bifido- } \\
\text { bacterium lactis, Lactobacillus reuteri }\end{array}$ & & 32 \\
\hline & Human & Lactobacillus plantarum DR7 & $\begin{array}{l}\text { Reducing plasma pro-inflammatory cytokines } \\
\text { and increasing plasma anti-inflammatory } \\
\text { cytokines, enhancing the serotonin pathway }\end{array}$ & 33 \\
\hline & $\begin{array}{l}\text { Human (patients } \\
\text { with chronic fatigue } \\
\text { syndrome [CFS]) }\end{array}$ & Lactobacillus casei strain Shirota (LcS) & & 34 \\
\hline & Mouse (ELS) & Lactobacillus plantarum PS128 & $\begin{array}{l}\text { Reducing serum corticosterone and inflamma- } \\
\text { tory cytokines, increasing anti-inflammatory } \\
\text { cytokines, modulating DA and 5-TH in PFC }\end{array}$ & 114 \\
\hline & Rat (CRS) & Lactobacillus helveticus NS8 & $\begin{array}{l}\text { Reducing plasma stress hormones, regulating } \\
\text { cytokines, and increasing hippocampal BDNF }\end{array}$ & 115 \\
\hline \multirow[t]{2}{*}{$\begin{array}{l}\text { Autism spectrum } \\
\text { disorder (ASD) }\end{array}$} & Mouse (shank3 KO) & Lactobacillus reuteri & $\begin{array}{l}\text { Regulating GABA receptor and oxytocin expres- } \\
\text { sion }\end{array}$ & 46 \\
\hline & $\begin{array}{l}\text { Mouse (shank3 KO, } \\
\text { BTBR) }\end{array}$ & Lactobacillus reuteri & Redulating oxytocin expression & 47 \\
\hline \multirow[t]{3}{*}{$\begin{array}{l}\text { Alzheimer's disease } \\
\text { (AD) }\end{array}$} & Human & $\begin{array}{l}\text { Lactobacillus acidophilus, Lactobacillus } \\
\text { casei, Bifidobacterium bifidum, Lactoba- } \\
\text { cillus fermentum }\end{array}$ & & 72 \\
\hline & Mouse $(3 x \operatorname{Tg})$ & $\begin{array}{l}\text { SLAB51 (Streptococcus thermophilus, Bifi- } \\
\text { dobacterium longum, B. breve, B. infantis, } \\
\text { Lactobacillus acidophilus, L. plantarum, L. } \\
\text { paracasei, L. delbrueckii subsp. bulgaricus, } \\
\text { L. brevis) }\end{array}$ & $\begin{array}{l}\text { Reducing oxidative stress by activating SIRT-1 } \\
\text { dependent mechanisms }\end{array}$ & 70 \\
\hline & $\begin{array}{l}\text { Rat (b-amyloid injec- } \\
\text { tion) }\end{array}$ & $\begin{array}{l}\text { Lactobacillus acidophilus, L. fermentum, } \\
\text { Bifidobacterium lactis, B. longum }\end{array}$ & & 71 \\
\hline Social stress & Human & Bifidobacterium longum 1714 & & 116 \\
\hline
\end{tabular}

CSDS, chronic social defeat stress; CUS, chronic unpredictable stress; ELS, early life stress; CRS, chronic restraint stress.

\section{CONCLUSIONS}

Recent studies have revealed the relationship between the gut microbiome and mental health conditions. The GI tract, which contains the gut microbiome, communicates with the brain via several pathways such as the vagus nerve, neurotransmitters, and immune system. Through this communication, the gut microbi- ome plays an important role in the maintenance of brain homeostasis. Studies using GF animals, antibiotic-induced gut dysbiosis, and FMT provide critical information about the role of the gut microbiome in several emotional and cognitive behaviors in psychiatric conditions. Using these methodologies, the correlation between various mental disorders and the gut microbiome has been clarified. In particular, there are ongoing attempts to treat or 
prevent mental disorders by regulating the gut microbiome using probiotics. Although various studies on gut dysbiosis and mental disorders have been conducted, these studies are limited in that they show some correlation, but not a causal relationship, between the gut microbiome and mental health.

Future research should focus on elucidating the details of how changes in the gut microbiome are involved in mental illness. For example, it will be necessary to look at what byproducts or metabolites are produced by changes in the gut microbiome and how they change brain function. Preclinical studies using animal models to study human mental disorders should be conducted under consistent conditions such as use of experimental animals of the same strain, sex and age to analyze the changes in gut microbiome and metabolites. In addition, clinical studies require analysis of a sufficient population of race, residential area, and sex. There is a need to develop advanced gut microbiome analysis methods. It is better to sample directly in the gut under endoscope (for humans) or gut tissues (for experimental animals) than to use samples from feces [117]. Through these approaches, it is necessary to establish a database of gut microbiome and metabolites for each animal model of mental disorders or for patients with mental disorders. In addition, more research is needed to study how gut dysbiosis observed in mental disorders affects the transmission of signals from the gut to the brain through the vagus nerve or spinal cord. Finally, it would be necessary to investigate the therapeutic specificity of probiotics to symptoms of mental illness for the discovery of new, precise treatments to prevent or improve mental disorders toward the goal of more personalized treatments. It is not easy to study how the changes in gut microbiome observed in mental disorders or by the treatment of probiotics affects the environment in the gut or the communication between the gut and the brain. Main reason is there was no in vitro model to study the gut microbiome and probiotics in the past. However, recently developed 3D human intestinal organoids or other in vitro models will accelerate this research [118]. To understand the mechanism of the improvement of mental disorders by probiotics, it will be helpful to elucidate molecular or physiological changes in neural circuitries of gutbrain axis using cutting-edge techniques such as next generation sequencing (NGS) or in vivo electrophysiology or calcium imaging.

\section{ACKNOWLEDGEMENTS}

This study was supported by the KBRI basic research program through KBRI funded by the Ministry of Science and ICT (20-BR02-06 and 20-BR-02-17).

\section{REFERENCES}

1. Turnbaugh PJ, Ley RE, Hamady M, Fraser-Liggett CM, Knight R, Gordon JI (2007) The human microbiome project. Nature 449:804-810.

2. Cryan JF, O'Riordan KJ, Cowan CSM, Sandhu KV, Bastiaanssen TFS, Boehme M, Codagnone MG, Cussotto S, Fulling C, Golubeva AV, Guzzetta KE, Jaggar M, Long-Smith CM, Lyte JM, Martin JA, Molinero-Perez A, Moloney G, Morelli E, Morillas E, O'Connor R, Cruz-Pereira JS, Peterson VL, Rea K, Ritz NL, Sherwin E, Spichak S, Teichman EM, van de Wouw M, Ventura-Silva AP, Wallace-Fitzsimons SE, Hyland N, Clarke G, Dinan TG (2019) The microbiota-gut-brain axis. Physiol Rev 99:1877-2013.

3. Huang TT, Lai JB, Du YL, Xu Y, Ruan LM, Hu SH (2019) Current understanding of gut microbiota in mood disorders: an update of human studies. Front Genet 10:98.

4. Vuotto C, Battistini L, Caltagirone C, Borsellino G (2020) Gut microbiota and disorders of the central nervous system. Neuroscientist 22:487-502.

5. Russo SJ, Nestler EJ (2013) The brain reward circuitry in mood disorders. Nat Rev Neurosci 14:609-625.

6. De Palma G, Blennerhassett P, Lu J, Deng Y, Park AJ, Green W, Denou E, Silva MA, Santacruz A, Sanz Y, Surette MG, Verdu EF, Collins SM, Bercik P (2015) Microbiota and host determinants of behavioural phenotype in maternally separated mice. Nat Commun 6:7735.

7. Campos AC, Rocha NP, Nicoli JR, Vieira LQ, Teixeira MM, Teixeira AL (2016) Absence of gut microbiota influences lipopolysaccharide-induced behavioral changes in mice. Behav Brain Res 312:186-194.

8. Lukić I, Getselter D, Koren O, Elliott E (2019) Role of tryptophan in microbiota-induced depressive-like behavior: evidence from tryptophan depletion study. Front Behav Neurosci 13:123.

9. Hoban AE, Moloney RD, Golubeva AV, McVey Neufeld KA, O'Sullivan O, Patterson E, Stanton C, Dinan TG, Clarke G, Cryan JF (2016) Behavioural and neurochemical consequences of chronic gut microbiota depletion during adulthood in the rat. Neuroscience 339:463-477.

10. Guida F, Turco F, Iannotta M, De Gregorio D, Palumbo I, Sarnelli G, Furiano A, Napolitano F, Boccella S, Luongo L, Mazzitelli M, Usiello A, De Filippis F, Iannotti FA, Piscitelli F, Ercolini D, de Novellis V, Di Marzo V, Cuomo R, Maione S (2018) Antibiotic-induced microbiota perturbation causes gut endocannabinoidome changes, hippocampal neuroglial reorganization and depression in mice. Brain Behav Immun 
67:230-245.

11. Szyszkowicz JK, Wong A, Anisman H, Merali Z, Audet MC (2017) Implications of the gut microbiota in vulnerability to the social avoidance effects of chronic social defeat in male mice. Brain Behav Immun 66:45-55.

12. Yang C, Fujita Y, Ren Q, Ma M, Dong C, Hashimoto K (2017) Bifidobacterium in the gut microbiota confer resilience to chronic social defeat stress in mice. Sci Rep 7:45942.

13. Marin IA, Goertz JE, Ren T, Rich SS, Onengut-Gumuscu S, Farber E, Wu M, Overall CC, Kipnis J, Gaultier A (2017) Microbiota alteration is associated with the development of stress-induced despair behavior. Sci Rep 7:43859.

14. Siopi E, Chevalier G, Katsimpardi L, Saha S, Bigot M, Moigneu C, Eberl G, Lledo PM (2020) Changes in gut microbiota by chronic stress impair the efficacy of fluoxetine. Cell Rep 30:3682-3690.

15. Jiang H, Ling Z, Zhang Y, Mao H, Ma Z, Yin Y, Wang W, Tang W, Tan Z, Shi J, Li L, Ruan B (2015) Altered fecal microbiota composition in patients with major depressive disorder. Brain Behav Immun 48:186-194.

16. Naseribafrouei A, Hestad K, Avershina E, Sekelja M, Linløkken A, Wilson R, Rudi K (2014) Correlation between the human fecal microbiota and depression. Neurogastroenterol Motil 26:1155-1162.

17. Chen JJ, Zheng P, Liu YY, Zhong XG, Wang HY, Guo YJ, Xie P (2018) Sex differences in gut microbiota in patients with major depressive disorder. Neuropsychiatr Dis Treat 14:647-655.

18. Zheng P, Zeng B, Zhou C, Liu M, Fang Z, Xu X, Zeng L, Chen J, Fan S, Du X, Zhang X, Yang D, Yang Y, Meng H, Li W, Melgiri ND, Licinio J, Wei H, Xie P (2016) Gut microbiome remodeling induces depressive-like behaviors through a pathway mediated by the host's metabolism. Mol Psychiatry 21:786-796.

19. Aizawa E, Tsuji H, Asahara T, Takahashi T, Teraishi T, Yoshida S, Ota M, Koga N, Hattori K, Kunugi H (2016) Possible association of Bifidobacterium and Lactobacillus in the gut microbiota of patients with major depressive disorder. J Affect Disord 202:254-257.

20. Lin P, Ding B, Feng C, Yin S, Zhang T, Qi X, Lv H, Guo X, Dong K, Zhu Y, Li Q (2017) Prevotella and Klebsiella proportions in fecal microbial communities are potential characteristic parameters for patients with major depressive disorder. J Affect Disord 207:300-304.

21. Chen Z, Li J, Gui S, Zhou C, Chen J, Yang C, Hu Z, Wang H, Zhong X, Zeng L, Chen K, Li P, Xie P (2018) Comparative metaproteomics analysis shows altered fecal microbiota signatures in patients with major depressive disorder. Neuroreport 29:417-425.
22. Valles-Colomer M, Falony G, Darzi Y, Tigchelaar EF, Wang J, Tito RY, Schiweck C, Kurilshikov A, Joossens M, Wijmenga C, Claes S, Van Oudenhove L, Zhernakova A, Vieira-Silva S, Raes J (2019) The neuroactive potential of the human gut microbiota in quality of life and depression. Nat Microbiol 4:623632.

23. Chen JJ, Zeng BH, Li WW, Zhou CJ, Fan SH, Cheng K, Zeng L, Zheng P, Fang L, Wei H, Xie P (2017) Effects of gut microbiota on the microRNA and mRNA expression in the hippocampus of mice. Behav Brain Res 322(Pt A):34-41.

24. Diaz Heijtz R, Wang S, Anuar F, Qian Y, Björkholm B, Samuelsson A, Hibberd ML, Forssberg H, Pettersson S (2011) Normal gut microbiota modulates brain development and behavior. Proc Natl Acad Sci U S A 108:3047-3052.

25. Luk B, Veeraragavan S, Engevik M, Balderas M, Major A, Runge J, Luna RA, Versalovic J (2018) Postnatal colonization with human "infant-type" Bifidobacterium species alters behavior of adult gnotobiotic mice. PLoS One 13:e0196510.

26. Neufeld KM, Kang N, Bienenstock J, Foster JA (2011) Reduced anxiety-like behavior and central neurochemical change in germ-free mice. Neurogastroenterol Motil 23:255264.

27. Arentsen T, Raith H, Qian Y, Forssberg H, Diaz Heijtz R (2015) Host microbiota modulates development of social preference in mice. Microb Ecol Health Dis 26:29719.

28. Huo R, Zeng B, Zeng L, Cheng K, Li B, Luo Y, Wang H, Zhou C, Fang L, Li W, Niu R, Wei H, Xie P (2017) Microbiota modulate anxiety-like behavior and endocrine abnormalities in hypothalamic-pituitary-adrenal axis. Front Cell Infect Microbiol 7:489.

29. Desbonnet L, Clarke G, Traplin A, O'Sullivan O, Crispie F, Moloney RD, Cotter PD, Dinan TG, Cryan JF (2015) Gut microbiota depletion from early adolescence in mice: Implications for brain and behaviour. Brain Behav Immun 48:165173.

30. Leclercq S, Mian FM, Stanisz AM, Bindels LB, Cambier E, Ben-Amram H, Koren O, Forsythe P, Bienenstock J (2017) Low-dose penicillin in early life induces long-term changes in murine gut microbiota, brain cytokines and behavior. Nat Commun 8:15062.

31. Messaoudi M, Violle N, Bisson JF, Desor D, Javelot H, Rougeot C (2011) Beneficial psychological effects of a probiotic formulation (Lactobacillus helveticus R0052 and Bifidobacterium longum R0175) in healthy human volunteers. Gut Microbes 2:256-261.

32. Colica C, Avolio E, Bollero P, Costa de Miranda R, Ferraro S, Sinibaldi Salimei P, De Lorenzo A, Di Renzo L (2017) Evi- 
dences of a new psychobiotic formulation on body composition and anxiety. Mediators Inflamm 2017:5650627.

33. Chong HX, Yusoff NAA, Hor YY, Lew LC, Jaafar MH, Choi SB, Yusoff MSB, Wahid N, Abdullah MFIL, Zakaria N, Ong KL, Park YH, Liong MT (2019) Lactobacillus plantarum DR7 alleviates stress and anxiety in adults: a randomised, doubleblind, placebo-controlled study. Benef Microbes 10:355-373.

34. Rao AV, Bested AC, Beaulne TM, Katzman MA, Iorio C, Berardi JM, Logan AC (2009) A randomized, double-blind, placebo-controlled pilot study of a probiotic in emotional symptoms of chronic fatigue syndrome. Gut Pathog 1:6.

35. Sandler RH, Finegold SM, Bolte ER, Buchanan CP, Maxwell AP, Väisänen ML, Nelson MN, Wexler HM (2000) Short-term benefit from oral vancomycin treatment of regressive-onset autism. J Child Neurol 15:429-435.

36. Kang DW, Adams JB, Gregory AC, Borody T, Chittick L, Fasano A, Khoruts A, Geis E, Maldonado J, McDonough-Means S, Pollard EL, Roux S, Sadowsky MJ, Lipson KS, Sullivan MB, Caporaso JG, Krajmalnik-Brown R (2017) Microbiota Transfer Therapy alters gut ecosystem and improves gastrointestinal and autism symptoms: an open-label study. Microbiome $5: 10$.

37. Parracho HM, Bingham MO, Gibson GR, McCartney AL (2005) Differences between the gut microflora of children with autistic spectrum disorders and that of healthy children. J Med Microbiol 54(Pt 10):987-991.

38. Finegold SM (2011) Desulfovibrio species are potentially important in regressive autism. Med Hypotheses 77:270-274.

39. Tomova A, Husarova V, Lakatosova S, Bakos J, Vlkova B, Babinska K, Ostatnikova D (2015) Gastrointestinal microbiota in children with autism in Slovakia. Physiol Behav 138:179187.

40. Zhang M, Ma W, Zhang J, He Y, Wang J (2018) A Analysis of gut microbiota profiles and microbe-disease associations in children with autism spectrum disorders in China. Sci Rep 8:13981.

41. Xu M, Xu X, Li J, Li F (2019) Association between gut microbiota and autism spectrum disorder: a systematic review and meta-analysis. Front Psychiatry 10:473.

42. Crumeyrolle-Arias M, Jaglin M, Bruneau A, Vancassel S, Cardona A, Daugé V, Naudon L, Rabot S (2014) Absence of the gut microbiota enhances anxiety-like behavior and neuroendocrine response to acute stress in rats. Psychoneuroendocrinology 42:207-217.

43. Desbonnet L, Clarke G, Shanahan F, Dinan TG, Cryan JF (2014) Microbiota is essential for social development in the mouse. Mol Psychiatry 19:146-148.
44. Buffington SA, Di Prisco GV, Auchtung TA, Ajami NJ, Petrosino JF, Costa-Mattioli M (2016) Microbial reconstitution reverses maternal diet-induced social and synaptic deficits in offspring. Cell 165:1762-1775.

45. Stilling RM, Moloney GM, Ryan FJ, Hoban AE, Bastiaanssen TF, Shanahan F, Clarke G, Claesson MJ, Dinan TG, Cryan JF (2018) Social interaction-induced activation of RNA splicing in the amygdala of microbiome-deficient mice. Elife 7:e33070.

46. Tabouy L, Getselter D, Ziv O, Karpuj M, Tabouy T, Lukic I, Maayouf R, Werbner N, Ben-Amram H, Nuriel-Ohayon M, Koren O, Elliott E (2018) Dysbiosis of microbiome and probiotic treatment in a genetic model of autism spectrum disorders. Brain Behav Immun 73:310-319.

47. Sgritta M, Dooling SW, Buffington SA, Momin EN, Francis MB, Britton RA, Costa-Mattioli M (2019) Mechanisms underlying microbial-mediated changes in social behavior in mouse models of autism spectrum disorder. Neuron 101:246259.

48. de Theije CG, Wopereis H, Ramadan M, van Eijndthoven T, Lambert J, Knol J, Garssen J, Kraneveld AD, Oozeer R (2014) Altered gut microbiota and activity in a murine model of autism spectrum disorders. Brain Behav Immun 37:197-206.

49. Mutlu EA, Gillevet PM, Rangwala H, Sikaroodi M, Naqvi A, Engen PA, Kwasny M, Lau CK, Keshavarzian A (2012) Colonic microbiome is altered in alcoholism. Am J Physiol Gastrointest Liver Physiol 302:G966-G978.

50. Llopis M, Cassard AM, Wrzosek L, Boschat L, Bruneau A, Ferrere G, Puchois V, Martin JC, Lepage P, Le Roy T, Lefèvre L, Langelier B, Cailleux F, González-Castro AM, Rabot S, Gaudin F, Agostini H, Prévot S, Berrebi D, Ciocan D, Jousse C, Naveau S, Gérard P, Perlemuter G (2016) Intestinal microbiota contributes to individual susceptibility to alcoholic liver disease. Gut 65:830-839.

51. Peterson VL, Jury NJ, Cabrera-Rubio R, Draper LA, Crispie F, Cotter PD, Dinan TG, Holmes A, Cryan JF (2017) Drunk bugs: Chronic vapour alcohol exposure induces marked changes in the gut microbiome in mice. Behav Brain Res 323:172-176.

52. Bjørkhaug ST, Aanes H, Neupane SP, Bramness JG, Malvik S, Henriksen C, Skar V, Medhus AW, Valeur J (2019) Characterization of gut microbiota composition and functions in $\mathrm{pa}^{-}$ tients with chronic alcohol overconsumption. Gut Microbes 10:663-675.

53. Jadhav KS, Peterson VL, Halfon O, Ahern G, Fouhy F, Stanton C, Dinan TG, Cryan JF, Boutrel B (2018) Gut microbiome correlates with altered striatal dopamine receptor expression in a model of compulsive alcohol seeking. Neuropharmacol- 
ogy 141:249-259.

54. Bull-Otterson L, Feng W, Kirpich I, Wang Y, Qin X, Liu Y, Gobejishvili L, Joshi-Barve S, Ayvaz T, Petrosino J, Kong M, Barker D, McClain C, Barve S (2013) Metagenomic analyses of alcohol induced pathogenic alterations in the intestinal microbiome and the effect of Lactobacillus rhamnosus GG treatment. PLoS One 8:e53028.

55. Lee K, Vuong HE, Nusbaum DJ, Hsiao EY, Evans CJ, Taylor AMW (2018) The gut microbiota mediates reward and sensory responses associated with regimen-selective morphine dependence. Neuropsychopharmacology 43:2606-2614.

56. Wang F, Meng J, Zhang L, Johnson T, Chen C, Roy S (2018) Morphine induces changes in the gut microbiome and metabolome in a morphine dependence model. Sci Rep 8:3596.

57. Cluny NL, Keenan CM, Reimer RA, Le Foll B, Sharkey KA (2015) Prevention of diet-induced obesity effects on body weight and gut microbiota in mice treated chronically with $\Delta$ 9-tetrahydrocannabinol. PLoS One 10:e144270.

58. Benjamin JL, Hedin CR, Koutsoumpas A, Ng SC, McCarthy NE, Prescott NJ, Pessoa-Lopes P, Mathew CG, Sanderson J, Hart AL, Kamm MA, Knight SC, Forbes A, Stagg AJ, Lindsay JO, Whelan K (2012) Smokers with active Crohn's disease have a clinically relevant dysbiosis of the gastrointestinal microbiota. Inflamm Bowel Dis 18:1092-1100.

59. Biedermann L, Brülisauer K, Zeitz J, Frei P, Scharl M, Vavricka SR, Fried M, Loessner MJ, Rogler G, Schuppler M (2014) Smoking cessation alters intestinal microbiota: insights from quantitative investigations on human fecal samples using FISH. Inflamm Bowel Dis 20:1496-1501.

60. Kiraly DD, Walker DM, Calipari ES, Labonte B, Issler O, Pena CJ, Ribeiro EA, Russo SJ, Nestler EJ (2016) Alterations of the Host Microbiome Affect Behavioral Responses to Cocaine. Sci Rep 6:35455.

61. Ballard C, Gauthier S, Corbett A, Brayne C, Aarsland D, Jones E (2011) Alzheimer's disease. Lancet 377:1019-1031.

62. Hill JM, Clement C, Pogue AI, Bhattacharjee S, Zhao Y, Lukiw WJ (2014) Pathogenic microbes, the microbiome, and Alzheimer's disease (AD). Front Aging Neurosci 6:127.

63. Friedland RP (2015) Mechanisms of molecular mimicry involving the microbiota in neurodegeneration. J Alzheimers Dis 45:349-362.

64. Zhao Y, Dua P, Lukiw WJ (2015) Microbial sources of amyloid and relevance to amyloidogenesis and Alzheimer's disease (AD). J Alzheimers Dis Parkinsonism 5:177.

65. Soscia SJ, Kirby JE, Washicosky KJ, Tucker SM, Ingelsson M, Hyman B, Burton MA, Goldstein LE, Duong S, Tanzi RE, Moir RD (2010) The Alzheimer's disease-associated amyloid beta-protein is an antimicrobial peptide. PLoS One 5:e9505.

66. Kumar DK, Choi SH, Washicosky KJ, Eimer WA, Tucker S, Ghofrani J, Lefkowitz A, McColl G, Goldstein LE, Tanzi RE, Moir RD (2016) Amyloid- $\beta$ peptide protects against microbial infection in mouse and worm models of Alzheimer's disease. Sci Transl Med 8:340ra72.

67. Harach T, Marungruang N, Duthilleul N, Cheatham V, Mc Coy KD, Frisoni G, Neher JJ, Fåk F, Jucker M, Lasser T, Bolmont T (2017) Reduction of Abeta amyloid pathology in APPPS1 transgenic mice in the absence of gut microbiota. Sci Rep 7:41802.

68. Minter MR, Hinterleitner R, Meisel M, Zhang C, Leone V, Zhang X, Oyler-Castrillo P, Zhang X, Musch MW, Shen X, Jabri B, Chang EB, Tanzi RE, Sisodia SS (2017) Antibiotic-induced perturbations in microbial diversity during post-natal development alters amyloid pathology in an aged $\mathrm{APP}_{\mathrm{SWE}} /$ $\mathrm{PS}_{\triangle \mathrm{E} 9}$ murine model of Alzheimer's disease. Sci Rep 7:10411.

69. Vogt NM, Kerby RL, Dill-McFarland KA, Harding SJ, Merluzzi AP, Johnson SC, Carlsson CM, Asthana S, Zetterberg H, Blennow K, Bendlin BB, Rey FE (2017) Gut microbiome alterations in Alzheimer's disease. Sci Rep 7:13537.

70. Bonfili L, Cecarini V, Cuccioloni M, Angeletti M, Berardi S, Scarpona S, Rossi G, Eleuteri AM (2018) SLAB51 Probiotic formulation activates SIRT1 pathway promoting antioxidant and neuroprotective effects in an AD mouse model. Mol Neurobiol 55:7987-8000.

71. Athari Nik Azm S, Djazayeri A, Safa M, Azami K, Ahmadvand B, Sabbaghziarani F, Sharifzadeh M, Vafa M (2018) Lactobacilli and bifidobacteria ameliorate memory and learning deficits and oxidative stress in $\beta$-amyloid (1-42) injected rats. Appl Physiol Nutr Metab 43:718-726.

72. Akbari E, Asemi Z, Daneshvar Kakhaki R, Bahmani F, Kouchaki E, Tamtaji OR, Hamidi GA, Salami M (2016) Effect of probiotic supplementation on cognitive function and metabolic status in Alzheimer's disease: a randomized, doubleblind and controlled trial. Front Aging Neurosci 8:256.

73. Kim MS, Kim Y, Choi H, Kim W, Park S, Lee D, Kim DK, Kim HJ, Choi H, Hyun DW, Lee JY, Choi EY, Lee DS, Bae JW, Mook-Jung I (2020) Transfer of a healthy microbiota reduces amyloid and tau pathology in an Alzheimer's disease animal model. Gut 69:283-294.

74. Burns AJ, Thapar N (2006) Advances in ontogeny of the enteric nervous system. Neurogastroenterol Motil 18:876-887.

75. Furness JB (2012) The enteric nervous system and neurogastroenterology. Nat Rev Gastroenterol Hepatol 9:286-294.

76. Yano JM, Yu K, Donaldson GP, Shastri GG, Ann P, Ma L, Nagler CR, Ismagilov RF, Mazmanian SK, Hsiao EY (2015) 
Indigenous bacteria from the gut microbiota regulate host serotonin biosynthesis. Cell 161:264-276.

77. Bellono NW, Bayrer JR, Leitch DB, Castro J, Zhang C, O'Donnell TA, Brierley SM, Ingraham HA, Julius D (2017) Enterochromaffin cells are gut chemosensors that couple to sensory neural pathways. Cell 170:185-198.

78. Anitha M, Vijay-Kumar M, Sitaraman SV, Gewirtz AT, Srinivasan S (2012) Gut microbial products regulate murine gastrointestinal motility via Toll-like receptor 4 signaling. Gastroenterology 143:1006-1016.

79. Altschuler SM, Escardo J, Lynn RB, Miselis RR (1993) The central organization of the vagus nerve innervating the colon of the rat. Gastroenterology 104:502-509.

80. Rinaman L (2010) Ascending projections from the caudal visceral nucleus of the solitary tract to brain regions involved in food intake and energy expenditure. Brain Res 1350:18-34.

81. Han W, Tellez LA, Perkins MH, Perez IO, Qu T, Ferreira J, Ferreira TL, Quinn D, Liu ZW, Gao XB, Kaelberer MM, Bohórquez DV, Shammah-Lagnado SJ, de Lartigue G, de Araujo IE (2018) Neural circuit for gut-induced reward. Cell 175:665-678.

82. Whitlock FA (1961) Some psychiatric consequences of gastreotomy. Br Med J 1:1560-1564.

83. O'Leary OF, Ogbonnaya ES, Felice D, Levone BR, C Conroy L, Fitzgerald P, Bravo JA, Forsythe P, Bienenstock J, Dinan TG, Cryan JF (2018) The vagus nerve modulates BDNF expression and neurogenesis in the hippocampus. Eur Neuropsychopharmacol 28:307-316.

84. Klarer M, Arnold M, Günther L, Winter C, Langhans W, Meyer U (2014) Gut vagal afferents differentially modulate innate anxiety and learned fear. J Neurosci 34:7067-7076.

85. Lv H, Zhao YH, Chen JG, Wang DY, Chen H (2019) Vagus nerve stimulation for depression: a systematic review. Front Psychol 10:64.

86. Chakravarthy K, Chaudhry H, Williams K, Christo PJ (2015) Review of the uses of vagal nerve stimulation in chronic pain management. Curr Pain Headache Rep 19:54.

87. Biggio F, Gorini G, Utzeri C, Olla P, Marrosu F, Mocchetti I, Follesa P (2009) Chronic vagus nerve stimulation induces neuronal plasticity in the rat hippocampus. Int J Neuropsychopharmacol 12:1209-1221.

88. Tan HE, Sisti AC, Jin H, Vignovich M, Villavicencio M, Tsang KS, Goffer Y, Zuker CS (2020) The gut-brain axis mediates sugar preference. Nature 580:511-516.

89. Kim DY, Heo G, Kim M, Kim H, Jin JA, Kim HK, Jung S, An M, Ahn BH, Park JH, Park HE, Lee M, Lee JW, Schwartz GJ, Kim SY (2020) A neural circuit mechanism for mechanosensory feedback control of ingestion. Nature 580:376-380.

90. Sengupta JN (2009) Visceral pain: the neurophysiological mechanism. Handb Exp Pharmacol (194):31-74.

91. Moloney RD, O'Mahony SM, Dinan TG, Cryan JF (2015) Stress-induced visceral pain: toward animal models of irritable-bowel syndrome and associated comorbidities. Front Psychiatry 6:15.

92. Kigerl KA, Hall JC, Wang L, Mo X, Yu Z, Popovich PG (2016) Gut dysbiosis impairs recovery after spinal cord injury. J Exp Med 213:2603-2620.

93. Kigerl KA, Zane K, Adams K, Sullivan MB, Popovich PG (2020) The spinal cord-gut-immune axis as a master regulator of health and neurological function after spinal cord injury. Exp Neurol 323:113085

94. Fasano A, Shea-Donohue T (2005) Mechanisms of disease: the role of intestinal barrier function in the pathogenesis of gastrointestinal autoimmune diseases. Nat Clin Pract Gastroenterol Hepatol 2:416-422.

95. Cani PD, Everard A, Duparc T (2013) Gut microbiota, enteroendocrine functions and metabolism. Curr Opin Pharmacol 13:935-940.

96. Takeda K, Akira S (2004) Microbial recognition by Toll-like receptors. J Dermatol Sci 34:73-82.

97. Cryan JF, Dinan TG (2012) Mind-altering microorganisms: the impact of the gut microbiota on brain and behaviour. Nat Rev Neurosci 13:701-712.

98. Hata T, Asano Y, Yoshihara K, Kimura-Todani T, Miyata N, Zhang XT, Takakura S, Aiba Y, Koga Y, Sudo N (2017) Regulation of gut luminal serotonin by commensal microbiota in mice. PLoS One 12:e0180745.

99. Maini Rekdal V, Bess EN, Bisanz JE, Turnbaugh PJ, Balskus EP (2019) Discovery and inhibition of an interspecies gut bacterial pathway for Levodopa metabolism. Science 364:eaau6323.

100. González-Arancibia C, Urrutia-Piñones J, Illanes-González J, Martinez-Pinto J, Sotomayor-Zárate R, Julio-Pieper M, Bravo JA (2019) Do your gut microbes affect your brain dopamine? Psychopharmacology (Berl) 236:1611-1622.

101. Beck BR, Park GS, Jeong DY, Lee YH, Im S, Song WH, Kang J (2019) Multidisciplinary and comparative investigations of potential psychobiotic effects of Lactobacillus strains isolated from newborns and their impact on gut microbiota and ileal transcriptome in a healthy murine model. Front Cell Infect Microbiol 9:269.

102. Siragusa S, De Angelis M, Di Cagno R, Rizzello CG, Coda R, Gobbetti M (2007) Synthesis of gamma-aminobutyric acid by lactic acid bacteria isolated from a variety of Italian 
cheeses. Appl Environ Microbiol 73:7283-7290.

103. Nishino R, Mikami K, Takahashi H, Tomonaga S, Furuse M, Hiramoto T, Aiba Y, Koga Y, Sudo N (2013) Commensal microbiota modulate murine behaviors in a strictly contamination-free environment confirmed by culture-based methods. Neurogastroenterol Motil 25:521-528.

104. Gareau MG, Wine E, Rodrigues DM, Cho JH, Whary MT, Philpott DJ, Macqueen G, Sherman PM (2011) Bacterial infection causes stress-induced memory dysfunction in mice. Gut 60:307-317.

105. Fröhlich EE, Farzi A, Mayerhofer R, Reichmann F, Jačan A, Wagner B, Zinser E, Bordag N, Magnes C, Fröhlich E, Kashofer K, Gorkiewicz G, Holzer P (2016) Cognitive impairment by antibiotic-induced gut dysbiosis: analysis of gut microbiota-brain communication. Brain Behav Immun 56:140-155.

106. Möhle L, Mattei D, Heimesaat MM, Bereswill S, Fischer A, Alutis M, French T, Hambardzumyan D, Matzinger P, Dunay IR, Wolf SA (2016) Ly6C(hi) Monocytes provide a link between antibiotic-induced changes in gut microbiota and adult hippocampal neurogenesis. Cell Rep 15:1945-1956.

107. Cammarota G, Ianiro G, Tilg H, Rajilić-Stojanović M, Kump P, Satokari R, Sokol H, Arkkila P, Pintus C, Hart A, Segal J, Aloi M, Masucci L, Molinaro A, Scaldaferri F, Gasbarrini G, LopezSanroman A, Link A, de Groot P, de Vos WM, Högenauer C, Malfertheiner P, Mattila E, Milosavljević T, Nieuwdorp M, Sanguinetti M, Simren M, Gasbarrini A; European FMT Working Group (2017) European consensus conference on faecal microbiota transplantation in clinical practice. Gut 66:569-580.

108. Kelly JR, Borre Y, O' Brien C, Patterson E, El Aidy S, Deane J, Kennedy PJ, Beers S, Scott K, Moloney G, Hoban AE, Scott L, Fitzgerald P, Ross P, Stanton C, Clarke G, Cryan JF, Dinan TG (2016) Transferring the blues: Depression-associated gut microbiota induces neurobehavioural changes in the rat. J Psychiatr Res 82:109-118.

109. Turnbaugh PJ, Ley RE, Mahowald MA, Magrini V, Mardis ER, Gordon JI (2006) An obesity-associated gut microbiome with increased capacity for energy harvest. Nature 444:1027-1031.

110. Bruce-Keller AJ, Salbaum JM, Luo M, Blanchard E 4th, Taylor
CM, Welsh DA, Berthoud HR (2015) Obese-type gut microbiota induce neurobehavioral changes in the absence of obesity. Biol Psychiatry 77:607-615.

111. Barrett E, Ross RP, O'Toole PW, Fitzgerald GF, Stanton C (2012) $\gamma$-Aminobutyric acid production by culturable bacteria from the human intestine. J Appl Microbiol 113:411-417.

112. O'Mahony SM, Clarke G, Borre YE, Dinan TG, Cryan JF (2015) Serotonin, tryptophan metabolism and the brain-gutmicrobiome axis. Behav Brain Res 277:32-48.

113. Liu WH, Yang CH, Lin CT, Li SW, Cheng WS, Jiang YP, Wu CC, Chang CH, Tsai YC (2015) Genome architecture of Lactobacillus plantarum PS128, a probiotic strain with potential immunomodulatory activity. Gut Pathog 7:22.

114. Liu YW, Liu WH, Wu CC, Juan YC, Wu YC, Tsai HP, Wang S, Tsai YC (2016) Psychotropic effects of Lactobacillus plantarum PS128 in early life-stressed and naïve adult mice. Brain Res 1631:1-12.

115. Liang S, Wang T, Hu X, Luo J, Li W, Wu X, Duan Y, Jin F (2015) Administration of Lactobacillus helveticus NS8 improves behavioral, cognitive, and biochemical aberrations caused by chronic restraint stress. Neuroscience 310:561-577.

116. Allen AP, Hutch W, Borre YE, Kennedy PJ, Temko A, Boylan G, Murphy E, Cryan JF, Dinan TG, Clarke G (2016) Bifidobacterium longum 1714 as a translational psychobiotic: modulation of stress, electrophysiology and neurocognition in healthy volunteers. Transl Psychiatry 6:e939.

117. Zmora N, Zilberman-Schapira G, Suez J, Mor U, Dori-Bachash M, Bashiardes S, Kotler E, Zur M, Regev-Lehavi D, Brik RB, Federici S, Cohen Y, Linevsky R, Rothschild D, Moor AE, Ben-Moshe S, Harmelin A, Itzkovitz S, Maharshak N, Shibolet O, Shapiro H, Pevsner-Fischer M, Sharon I, Halpern Z, Segal E, Elinav E (2018) Personalized gut mucosal colonization resistance to empiric probiotics is associated with unique host and microbiome features. Cell 174:1388-1405.

118. Son YS, Ki SJ, Thanavel R, Kim JJ, Lee MO, Kim J, Jung CR, Han TS, Cho HS, Ryu CM, Kim SH, Park DS, Son MY (2020) Maturation of human intestinal organoids in vitro facilitates colonization by commensal lactobacilli by reinforcing the mucus layer. FASEB J 34:9899-9910. 